\title{
The Multiple Effects of Capital Controls
}

\author{
Chokri Zehri (iD \\ Assistant professor of economics, Prince Sattam Bin Abdulaziz University, College \\ of Sciences and Humanities in Al-Sulail, Department of Business Administration, \\ Al-Sulail, Saudi Arabia, e-mail: c.alzhari@psau.edu.sa
}

\section{Abstract}

Capital controls are seen as a means to promote financial stability or improve macroeconomic adjustment in economies with nominal rigidities and suboptimal monetary policy. Such controls may take various forms, including explicit or implicit taxation of cross-border financial flows and dual or multiple exchange rate systems. Using a quarter dataset on capital controls actions in 27 emerging economies from 2010 to 2018 , the study analyzes the effectiveness of capital controls (CCs) along different angles. Since the 2008 financial crisis, strengthening capital controls has allowed more monetary policy autonomy and exchange rate stability, verifying the Mundell-Fleming trilemma model. Following CCs, the results show that accumulating international reserves may compensate for the loss of inflows and lead to more effective policies. Tighter CCs on inflows cause significant spillovers, specifically in the conditions of liquidity abundance. These spillovers originate from the problem of policy coordination of emerging economies and are mainly caused by capital controls being used as an instrument to manage capital flows. For governments that have to manage the risks associated with inflow surges or disruptive outflows, capital controls need to play a key role.

Keywords: capital, controls, flows, impacts

JEL: F21, F32, F41, F42

\section{Introduction}

It is important to understand international capital flows to enhance macroeconomic stability and design effective economic policies. Effective capital controls (CCs) reduce the volume of capital flows, alter the composition from short-term to long-term capital flows, make exchange rates more stable, and allow monetary policy autonomy 
(Magud et al. 2018, p. 114). Previous studies highlighted various problems concerning CCs, but it is unclear whether these controls achieve their objective or not (Korinek 2011, p. 76; Bianchi and Mendoza 2011, p. 45; Benigno et al. 2013, p. 73). The identified problems include the absence of a theoretical framework to define the macroeconomic consequences of these controls, the heterogeneity between countries that apply CCs, and the success of these restrictions. Several studies have also identified the difficulties that occur due to isolating the direct effect of CCs, which limits the success of capital flows and their objectives (Fernandez et al. 2015, p. 82; Forbes et al. 2015, p. 32; Alfaro et al. 2017, p. 112).

CCs are used in countries all around the globe, but their effectiveness is still not clear. It complicates the development of a standard of best practices to accomplish the influential regulation of international capital flows due to the specific characteristics of economies and different market responses (Forbes et al. 2015, p. 41). There are two aspects of studying the effectiveness of CCs: (a) actions on capital control and (b) achieving macroeconomic objectives (autonomy of monetary policy, reduction of exchange rate pressures, etc.).

The present study discusses the impact of controls on emerging markets. After the Great Recession of 2008, several economies used restrictions, especially on short term capital inflows, while others increased restrictions (Fernandez et al. 2015, p. 61). This study is associated with the studies of monetary policy and exchange policy in influencing the nature of the financial crisis. Recently, monetary policy has been restricted by the global financial cycle under a flexible exchange rate regime when capital flow management is preferable to maintain monetary autonomy, and there is free capital mobility (Rey 2015, p. 83; Passari and Rey 2015, p. 22). Optimal CCs and monetary policy were explored with small, open countries, considering risk premium shocks (Farhi and Werning 2014, p. 15). Those studies reported that CCs retain monetary autonomy in a fixed exchange rate and work as trade manipulation in a flexible exchange rate regime. Exchange rate policies are beneficial to lower the severity of a financial crisis beyond CCs (Benigno et al. 2016, p. 31; Chamon and Garcia 2016, p. 152). Likewise, Devereux, Young, and Yu (2017) showed that CCs can be considered state-improving tools when optimally merged with monetary policy in the presence of policy commitment. Many older studies on CCs focused on the incompatibility triangle, so CCs were usually related to the hope of keeping a degree of autonomy of the monetary policy while applying fixed exchange regimes. In the last several years, some emerging economies (EEs) have tended to use a more flexible exchange rate. The fear of floating will cause these countries to intervene massively on the exchange markets or to vary their director rate to prevent huge fluctuations in the exchange rate.

We contribute to previous empirical studies in two ways. First, we use a recent, large dataset on capital control acts, which allow us to more exactly detect the policy whose efficiency is evaluated. Most of the previous studies on the effectiveness of CCs used infrequent data, usually annual. Capital control measures thus used are less precise, and they suffer from two essential shortcomings: they do not reflect the fair intensi- 
ty of their application among countries, and they are often confused with other policies simultaneously applied with CCs. The use of quarterly data in this study allows for a larger time interval and allows for a more correct analysis of the actions taken by policymakers.

Second, the effectiveness of CCs is examined using a model that regroups the components of the monetary policy trilemma, which indicates that it is difficult to use a fixed exchange rate, together with an independent monetary policy and an open capital account. These components are usually studied independently. A major contribution of the paper is to regroup the three elements of the incompatibility triangle into one model. The incompatibility triangle framework also shows that the de jure and de facto changes in the opening of a capital account are related (Rebucci and Ma 2019, p. 35). This is how we can examine whether the applied controls are effective from this incompatibility triangle. Thus, using a panel VAR model, we test whether capital markets affect both monetary policy autonomy and changes in the exchange rate. As presented in several studies, CCs are endogenous, which highlights the recurrent changes in these controls among countries, and, therefore, we will know their repercussions on other macroeconomic policies. To the best of our knowledge, there is no previous study that used a panel VAR approach to study the repercussions of CC changes on monetary and exchange policies.

As regards CC effects, we analyze domestic and multilateral impacts. Domestically, our main finding is that by reducing capital inflows, CCs make it possible to better stabilize the economy. It allows more independence to monetary policy and allows less pressure on the exchange policy at which the exchange rate manifests slight fluctuations.

Empirical evidence shows that EEs accumulated excessive international reserves after the 2008 crisis. Our study has shown that despite the strict capital controls applied by several emerging countries after the crisis, it did not prevent the accumulation of reserves. The latter supported the decisions of monetary policy and exchange rate policy. To the best of our knowledge, few previous studies have highlighted the association between capital control actions with the accumulation of international reserves (Jeanne 2016, p. 52; Korinek 2018, p. 86).

For the multilateral effects, the study presents an understanding of the spillovers that may happen following restrictions applied by a country. Other countries will be affected after the migration of capital flows to their frontiers. Little empirical evidence exists on this spillover effect (Forbes et al. 2017, p. 112; Lambert et al. 2011, p. 165). We are among the first to demonstrate empirically these policy changes towards capital controls as a reaction to the early policy of another country which has already applied similar controls.

Our paper is organized as follows. After presenting the literature review of the effectiveness of CCs in Section 2, we present the data and methodology in Section 3. The results of the model regressions are presented in Section 4. The last section gives conclusions. 


\section{Literature review}

\section{Multiple effects on monetary and exchange policies}

The theoretical and empirical literature on the effectiveness of CC on monetary and exchange policies has several methodological shortcomings. There are several criticisms of the indexes used to reflect the intensity of CC. It is often difficult to separate the effects caused by the controls from the effects caused by other macroeconomic policies, such as the effectiveness of prudential supervision. CCs have been successful in different countries; however, the degree of success is not equal for all countries.

The empirical literature shows multiple impacts of CCs on proxy variables of monetary and exchange policies. Some recent studies have shown evidence that these controls can effectively affect the monetary and exchange policies under some macroeconomic conditions, and they also can protect economies from external shocks (Pasricha et al. 2018, p. 176; Magud et al. 2018, p. 51). Some studies focused on the macroeconomic framework in which CCs are instituted. Among these studies, Bayoumi et al. (2015) studied 37 countries that introduced outflow restrictions from 1995-2010. They found evidence that capital outflow restrictions reduce the pressure on both policies under certain conditions. These conditions include strong macroeconomic fundamentals (growth rate, inflation, and fiscal and current account balances), good institutions (World Bank Governance Effectiveness Index), and existing restrictions (intensity of CCs or comprehensiveness). When none of the three conditions are met, controls will fail to support these policies. Furthermore, some studies suggest that controls are more effective in advanced countries than in others, perhaps because of the better quality of institutions and regulations (Binici et al. 2010).

Some recent studies (Pasricha et al. 2018; Magud et al. 2018) analyzed the conditions of success of capital controls and especially their impacts on the country that applies these controls compared to countries that did not apply these restrictions. Pasricha et al. (2018) used a recent frequency dataset on capital control instruments in 16 emerging market economies from 2001 to 2012. They give novel evidence on the domestic and multilateral impacts of these instruments. Increases in financial liberalization constrain monetary policy autonomy and decrease exchange rate instability, confirming the incompatibility trilemma. Magud et al. (2018) presented a meta-analysis of the literature on CCs, seeking to standardize the results of nearly 40 empirical studies. They build two indices of capital controls: the Capital Controls Effectiveness Index and the Weighted Capital Controls Effectiveness Index. Their results show that CCs on inflows seem to make monetary policy more independent, and they alter the composition of capital flows (Zehri 2020, a); there is less evidence that they reduce real exchange rate pressures. Kim and Yang (2012) determined that a fixed exchange rate allows CCs to support the independence of the monetary policy. This impact is clearer with wide and long term CCs. 
Klein and Shambaugh (2015) found that economies with large CCs are more covered concerning external monetary shocks. Meanwhile, Liu and Spiegel (2015) showed that the wide use of CCs allows countries to maintain a desired interest rate differential between domestic and foreign markets. However, these strict controls did not have any link with the currency appreciation detected in some countries in their sample. Ito, McCauley, and Chan (2015) studied a small open economy and focused on simple policy rules, while Devereux et al. (2019) investigated the optimal monetary policy and optimal CC. A model with fixed exchange rates, downward nominal wage rigidities, and free capital mobility was presented by Bayoumi et al. (2015), where an optimal devaluation eliminates the effects of the wage rigidity.

Table 1 summarizes the results of most studies on this issue and shows that the "Unclear" effect dominates the findings.

Table 1. Summary of studies' results

\begin{tabular}{|l|c|c|}
\hline \multicolumn{1}{|c|}{ Study } & $\begin{array}{c}\text { Reducing Real Exchange Rate } \\
\text { Pressure }\end{array}$ & Control on Inflows \\
\hline Brazil & Unclear & Unclear \\
\hline Chile & Unclear & Unclear \\
\hline Colombia & Unclear & Unclear \\
\hline Malaysia (1989) & Yes & Yes \\
\hline Malaysia (1994) & Unclear & Yes \\
\hline Thailand & Unclear & Unclear \\
\hline Malaysia (1998) & Yes & Yes \\
\hline & Control on Outflows & Unclear \\
\hline Brazil & Yes & Yes \\
\hline Chile & Unclear & Unclear \\
\hline Colombia & Yes & Unclear \\
\hline Thailand & Unclear & Unclear \\
\hline Multi-country studies & Unclear & \\
\hline
\end{tabular}

Source: author's own elaboration.

\section{Indexes of capital controls}

It is difficult to give an exact measure of CC. The pre-2008 crisis literature utilizes indexes that measure the degree of capital restrictions. These indexes usually serve to set the extent of restrictions (the kind of transactions controlled) and then define what is the most appropriate when evaluating the effectiveness of controls. Many improvements in measuring CCs have been made in the recent literature. The relevant novelties of these studies gather data on variations in institutional arrangements (Edison and Warnock 2003, p. 63; Ocampo, Spiegel and Stiglitz 2008, p. 23; Qureshi, Ostry, Ghosh, and Chamon 2011, p. 91). The advantage of this method is that it precisely determines 
the type of policy action that is consistent with the time of the action. As discussed in the introduction, the puzzle of the similarities of policy effects over time and across EEs continues to appear with this approach.

Older studies utilized diverse approaches to improve the distinction of capital control impacts. These approaches can be arranged into two classes: the first, called "splitting-the-announcements" method, aims to define similar and homogeneous macroeconomic policies. Quantitatively, these policies must have relatively identical impacts, especially on capital inflows. This needs to rearrange the controls established in more homogeneous subgroups of controls. The second aims to compute the opportunity cost of certain variations in regulation. This can be achieved by computing a tax rate of the control actions (Benigno et al. 2016, p. 31; Forbes et al. 2016, p. 162; Baba and Kokenyne 2011, p. 151). Unfortunately, this effective tax is only applied for a certain type of policy tool (e.g., unremunerated reserve requirements), which form a minority of the actions made by EEs.

In this study, we combine the advantages of both approaches by employing indexes constructed recently in some empirical studies (Fernández et al. 2016; Chinn and Ito 2008). Fernández et al. (2016) presented a new data set of CCs divided into ten asset categories along with the structure of inflows and outflows. These indexes were applied to 100 economies over the period 1995-2013. Our study uses the first three indexes among the ten asset categories of CC: ka, kai, and kao (controls applied respectively to gross flows, inflows, and outflows). Chinn and Ito (2008) create a new index that measures the extent of openness in capital account transactions, this index is termed kaopen, and it was regularly updated (the last update is there of 2017). Table 2 summarizes these indexes.

Table 2. Capital Control Indexes

\begin{tabular}{|c|c|c|}
\hline Index & Definition & Source \\
\hline ka & $\begin{array}{l}\text { Overall restrictions index (all asset cate- } \\
\text { gories) }\end{array}$ & \multirow{2}{*}{$\begin{array}{l}\text { Fernández, Klein, Rebucci, Schindler, and } \\
\text { Uribe (2016) "Capital Control Measures: } \\
\text { A New Dataset" }\end{array}$} \\
\hline kai & $\begin{array}{l}\text { Overall inflow restrictions index (all asset } \\
\text { categories) }\end{array}$ & \\
\hline kao & $\begin{array}{l}\text { Overall outflow restrictions index (all asset } \\
\text { categories) }\end{array}$ & \\
\hline kaopen & $\begin{array}{l}\text { The extent of openness in capital account } \\
\text { transactions }\end{array}$ & $\begin{array}{l}\text { Chinn, M.D., and H. Ito, The Chinn-Ito } \\
\text { Index, http://web.pdx.edu/ ito/Chinn-Ito } \\
\text { _website.htm, last updated July } 2017\end{array}$ \\
\hline
\end{tabular}

Source: author's own elaboration.

The principal distinction between both indexes is that the kaopen index is a larger measure of capital account liberalization, including regulations to the current account of the balance of payments and the foreign exchange market, while the dataset of Fernández et al. (2016) is smaller, focusing especially on capital flows. However, it has further details on the intensity of controls, with distribution data on ten asset 
categories. The indexes of Fernández et al. (2016) make it possible to detect more time change when countries set regulations than the Chinn-Ito index.

These indexes of Chinn and Ito (2008) and Fernández et al. (2016) capture the cross-country changes in the level of capital account liberalization; unfortunately, however, they are smaller in the time scope due to the way they are built and their annual frequency. To overcome these shortcomings, we propose duplicating the annual value of each of these indexes in 4 equal sub-values, as if they were quarterly data. This does nothing to diminish the robustness of this analysis since CCs are often long-term political instruments. This change will allow consistency with the frequency of the other variables in the model, which are quarterly.

\section{Data and methodology}

Capital control instruments may affect a set of variables, but at the same time, they can be affected by these variables. Thus, we use a panel VAR model. This model includes a system of equations in which the dependent variables will be representative of CCs, capital flows, monetary policy, and exchange rate policy. Our sample includes 27 EEs that used CCs over the period 2010Q1 to 2018Q4.

We use the interest rate differential as a proxy for monetary policy independence (rate variable). A country that maintains a differential of the domestic and external interest rate makes it possible to act on the volume of capital inflows and, consequently, to freely define a domestic interest rate without having a constraint with the external rate. The standard deviation of the bilateral exchange rate (to the US \$) is a proxy used for the volatility of the exchange rate (the $x$ chge variable). To separate the effect of the capital flows variables, we distribute them between inflows (the infl variable) and outflows (the outf variable), and for the global flows, we use the "gross" variable. Also, we include a set of exogenous variables to control for drivers that can influence the endogenous variables (the short-term interest rate in the United States (us_rate), the price of oil (oil), real gross domestic product growth in the United States $(g d p)$ and international reserves (ir). The impact of CCs used by the country can affect the inflows to other countries, and these spillover effects are presented by the variable (spill).

A panel VAR is the baseline model. The independent variables of this model are all considered endogenous and are explained by the set of exogenous variables previously cited. The model is written as follow:

$$
Y_{i, t}=\alpha_{0}+Z_{1} y_{i, t-1}+\ldots+Z_{n} y_{i, t-n}+W_{1} x_{i, t-1}+\ldots+W_{m} x_{i, t-m}+F E_{i}+E_{i, t}
$$

Our model is described by a system of equations, where $\mathrm{Y}_{\mathrm{t}}$ is the vector of endogenous variables for country $i, \mathrm{x}_{\mathrm{t}}$ is the vector of exogenous variables common to all countries, $\mathfrak{E}_{\mathrm{i}, \mathrm{t}}$ is the vector of residuals, and " $\mathrm{Z}$ " and " $\mathrm{W}$ " represent the coefficients for the endogenous and exogenous variables, respectively. Factors that have omitted 
and that can affect the dynamics of the model (e.g., administration efficiency) are regrouped in the term $\mathrm{FE}_{\mathrm{i}}$, which represents the country fixed effects ( $F E$ variable).

To examine if the cross-sectional changes in CC can be well used, we regress the model with the use of the Chinn-Ito (Chinn and Ito 2008) and Fernández et al., (2016) indexes. All of the explicative variables are introduced with one lag difference. Additionally, we propose a regression with the levels of these indexes and analyze the effect of a shock to them.

\section{Results}

In this section, we present the evidence from the estimation of the PVAR model for the period 2010:1-2018:4. We analyze if variations in CCs affect monetary and exchange rate policies and are under the forecasts of the incompatibility triangle. We also investigate the impact on international reserves and the multilateral effects. We examine the effect of a shock on CC, considered it as an inside policy instrument, and on different national policy variables, including differential interest rate, exchange rate volatility, capital movements, international reserves accumulation, and spillover effect.

The results of the PVAR analysis are displayed in Table 3. They show a positive and significant coefficient of the changes in "ka" and "kaopen" in the equation in which the differential interest rate is the independent variable. These findings show that changes in capital controls raise the differential of the interest rate and subsequently allow more autonomy of the monetary policy. The two other indexes of capital controls (kai and kao) do not affect the monetary policy. The results present negative and significant coefficients of the changes in "ka" and "kaopen" in the equation of exchange rate volatility (compared to the US dollar) suggesting that capital controls support the stability of the exchange rate policy, i.e., more liberalization is conducive to higher exchange rate instability.

Table 3. PVAR Analysis

\begin{tabular}{|l|l|r|r|r|r|r|r|}
\cline { 2 - 8 } \multicolumn{2}{c|}{} & Coefficient & Std. Err. & \multicolumn{1}{c|}{ Z } & \multicolumn{1}{c|}{ P>|z| } & \multicolumn{2}{|c|}{$[95 \%$ Conf. Interval] } \\
\hline \multirow{4}{*}{ rate } & ka & 0.019 & 0.055 & 2.17 & 0.006 & -0.998 & 0.118 \\
\cline { 2 - 8 } & kai & 0.049 & 0.767 & 0.58 & 0.365 & 0.915 & 3.157 \\
\cline { 2 - 8 } & kao & 0.035 & 0.858 & 0.15 & 0.247 & 0.758 & 2.549 \\
\cline { 2 - 8 } & kaopen & 0.541 & 0.467 & 3.58 & 0.000 & 1.625 & 4.457 \\
\cline { 2 - 8 } & xchge & -0.227 & -0.569 & -4.00 & 0.000 & -0.339 & -0.116 \\
\cline { 2 - 8 } & gross & 0.041 & 0.467 & 0.58 & 0.365 & 1.625 & 4.457 \\
\cline { 2 - 8 } & spill & 0.045 & 0.658 & 1.15 & 0.247 & 0.958 & 3.549 \\
\cline { 2 - 8 } & ir & 0.7195 & 0.085 & 2.44 & 0.000 & -0.738 & 0.218 \\
\hline
\end{tabular}




\begin{tabular}{|c|c|c|c|c|c|c|c|}
\hline \multirow{2}{*}{ xchge } & \multirow[b]{2}{*}{ ka } & \multirow{2}{*}{$\begin{array}{c}\text { Coefficient } \\
-0.319\end{array}$} & \multirow{2}{*}{$\begin{array}{c}\text { Std. Err. } \\
-0.085\end{array}$} & \multirow{2}{*}{$\frac{Z}{-2.44}$} & \multirow{2}{*}{$\frac{P>|z|}{0.000}$} & \multicolumn{2}{|c|}{ [95\% Conf. Interval] } \\
\hline & & & & & & -0.738 & 0.218 \\
\hline & kai & 0.228 & 0.407 & 0.15 & 0.297 & 0.559 & 0.659 \\
\hline & kao & 0.139 & 0.415 & 1.05 & 0.009 & 0.098 & 0.982 \\
\hline & kaopen & -0.742 & 0.283 & -3.62 & 0.000 & -0.128 & -0.018 \\
\hline & rate & -0.396 & -0.437 & -2.24 & 0.032 & 0.223 & 0.970 \\
\hline & gross & 0.180 & 0.150 & 1.06 & 0.063 & 0.147 & 0.575 \\
\hline & spill & 0.596 & 0.437 & 1.45 & 0.068 & 0.123 & 0.770 \\
\hline & ir & 0.096 & 0.537 & 1.68 & 0.148 & 0.253 & 0.958 \\
\hline \multirow[t]{8}{*}{ ir } & ka & 0.096 & 0.427 & 3.24 & 0.001 & 0.213 & 0.854 \\
\hline & kai & 0.141 & 0.592 & 2.38 & 0.005 & 1.925 & 3.257 \\
\hline & kao & 0.345 & 0.456 & 0.85 & 0.517 & 0.468 & 1.549 \\
\hline & kaopen & 0.080 & 0.350 & 2.06 & 0.013 & 0.147 & 0.575 \\
\hline & rate & 0.358 & 0.157 & 1.35 & 0.587 & 0.257 & 1.970 \\
\hline & xchge & 0.326 & 0.254 & 0.14 & 0.000 & 0.683 & 0.870 \\
\hline & gross & 0.754 & 0.076 & 2.14 & 0.000 & 0.013 & 0.940 \\
\hline & spill & 0.546 & 0.157 & 3.08 & 0.000 & 0.983 & 1.835 \\
\hline \multirow[t]{8}{*}{ spill } & ka & 0.236 & 0.057 & 0.35 & 0.568 & 0.157 & 1.970 \\
\hline & kai & 0.258 & 0.322 & 3.15 & 0.000 & 0.059 & 0.659 \\
\hline & kao & 0.009 & 0.015 & 0.85 & 0.009 & 0.098 & 0.982 \\
\hline & kaopen & 0.046 & 0.257 & 2.29 & 0.000 & 0.145 & 0.970 \\
\hline & rate & 0.127 & 0.154 & 1.35 & 0.437 & 0.178 & 0.754 \\
\hline & xchge & 0.458 & 0.022 & 0.15 & 0.197 & 0.059 & 0.659 \\
\hline & gross & 0.359 & 0.415 & 2.05 & 0.009 & 0.098 & 0.982 \\
\hline & ir & 0.101 & 0.037 & 1.32 & 0.302 & 0.021 & 0.587 \\
\hline
\end{tabular}

Source: author's own calculations.

The trilemma is confirmed using the index related to gross flows (ka). However, for the two other indexes, for inflow and outflow controls (kai and kao), the results are insignificant. By using the Chinn-Ito index, the results support the compromises of the incompatibility triangle. Decomposing the annual data from these indexes into quarterly data is very useful. It made it possible to have a greater frequency of data, and it also made it possible to highlight the variations made to these restrictive policies in the short term.

The Granger causality test, presented in Table 4, confirms the previous results. It demonstrates the presence of causality between the indexes of capital controls with the "rate" and "xchge," i.e., CC actions cause monetary and exchange policies. 
Chokri Zehri

Table 4. Granger Causality Test

\begin{tabular}{|c|c|c|c|}
\hline Equation & Excluded & Chi2 & Prob > chi2 \\
\hline \multirow[t]{8}{*}{ rate } & ka & 15.983 & 0.000 \\
\hline & kai & 35.367 & 0.002 \\
\hline & kao & 23.687 & 0.004 \\
\hline & kaopen & 27.692 & 0.000 \\
\hline & xchge & 57.427 & 0.000 \\
\hline & gross & 13.548 & 0.041 \\
\hline & spill & 55.327 & 0.021 \\
\hline & ir & 17.692 & 0.000 \\
\hline \multirow[t]{8}{*}{ xchge } & ka & 6.833 & 0.009 \\
\hline & kai & 35.367 & 0.002 \\
\hline & kao & 26.324 & 0.013 \\
\hline & kaopen & 23.687 & 0.004 \\
\hline & rate & 27.692 & 0.000 \\
\hline & gross & 36.324 & 0.000 \\
\hline & spill & 12.568 & 0.312 \\
\hline & ir & 9.254 & 0.048 \\
\hline \multirow[t]{8}{*}{ ir } & ka & 12.505 & 0.009 \\
\hline & kai & 35.312 & 0.002 \\
\hline & Kao & 23.639 & 0.004 \\
\hline & kaopen & 47.615 & 0.000 \\
\hline & rate & 23.622 & 0.004 \\
\hline & xchge & 67.692 & 0.000 \\
\hline & gross & 18.257 & 0.024 \\
\hline & spill & 54.576 & 0.000 \\
\hline
\end{tabular}

Source: author's own calculations.

As displayed in Table 5, this causality is bidirectional for the indexes "ka" and "kaopen," and is unidirectional for the "kai" and "kao" indexes.

Table 5. Direction of Causality

\begin{tabular}{|c|c|c|c|}
\hline Null Hypothesis & F-Statistic & Prob. & Remarks \\
\hline \multicolumn{4}{|c|}{ Ka index } \\
\hline Ka does not Granger cause rate & 7.888 & 0.001 & \multirow[t]{2}{*}{ Bidirectional } \\
\hline rate does not Granger cause ka & 4.296 & 0.015 & \\
\hline ka does not Granger cause debt xchge & 9.970 & 0.000 & \multirow[t]{2}{*}{ Bidirectional } \\
\hline xchge does not Granger cause ka & 2.662 & 0.073 & \\
\hline \multicolumn{4}{|c|}{ Kai index } \\
\hline kai does not Granger cause rate & 15.348 & 0.007 & Unidirectional \\
\hline rate does not Granger cause kai & 36.872 & 0.359 & \\
\hline kai does not Granger cause xchge & 25.687 & 0.025 & Unidirectional \\
\hline xchge does not Granger cause kai & 8.657 & 0.252 & \\
\hline
\end{tabular}




\begin{tabular}{|c|c|c|c|}
\hline Null Hypothesis & F-Statistic & Prob. & Remarks \\
\hline \multicolumn{4}{|c|}{ Kao index } \\
\hline kao does not Granger cause rate & 25.315 & 0.017 & Unidirectional \\
\hline rate does not Granger cause kao & 43.482 & 0.359 & \\
\hline kao does not Granger cause xchge & 15.587 & 0.005 & Unidirectional \\
\hline xchge does not Granger cause kao & 29.157 & 0.252 & \\
\hline \multicolumn{4}{|c|}{ Kaopen index } \\
\hline kaopen does not Granger cause rate & 45.302 & 0.017 & Bidirectional \\
\hline rate does not Granger cause kaopen & 15.459 & 0.009 & \\
\hline kaopen does not Granger cause xchge & 41.526 & 0.002 & Bidirectional \\
\hline xchge does not Granger cause kaopen & 27.037 & 0.000 & \\
\hline
\end{tabular}

Source: author's own calculations.

We suppose that the vector of endogenous variables listed in the system represented as $Y_{t}=$ [rate, xchge, ir, and spill]. To investigate the fraction of the fluctuations in the endogenous variables that are due to the capital controls shock, Table 6 summarizes the forecast-error variance decomposition. The findings show that unpredicted changes in the "ka" and "kaopen" indexes explain a large percentage of the dynamics in the differential interest rate $(78.1 \%$ and $78.8 \%$, respectively) and the exchange rate fluctuation $(78.4 \%$ and $81.5 \%$, respectively) at the 4 -quarters horizon.

Concerning the impact on international reserves for four quarters ahead, the "ka" and "kaopen" shocks explain $75.4 \%$ and $52.1 \%$, respectively, the variation in international reserves, and $59.5 \%$ and $52.1 \%$, respectively, the variation in spillovers. The impact of the CC indexes shocks on "spill" is also great, demonstrating that CCs are extremely conducive to spillover on other countries.

Table 6. Forecast-error variance decomposition due to a CC shocks

\begin{tabular}{|c|c|c|c|c|}
\hline Variable & 1 quarter ahead & 2 quarters ahead & 3 quarters ahead & 4 quarters ahead \\
\hline \multicolumn{5}{|c|}{$\mathrm{Ka}$} \\
\hline rate & 0.002 & 0.141 & 0.258 & 0.380 \\
\hline xchge & 0.456 & 0.242 & 0.151 & 0.025 \\
\hline ir & 0.154 & 0.178 & 0.197 & 0.225 \\
\hline spill & 0.054 & 0.148 & 0.165 & 0.228 \\
\hline \multicolumn{5}{|c|}{ Kaopen } \\
\hline rate & 0.015 & 0.141 & 0.258 & 0.374 \\
\hline xchge & 0.501 & 0.232 & 0.057 & 0.025 \\
\hline ir & 0.201 & 0.185 & 0.074 & 0.061 \\
\hline spill & 0.021 & 0.101 & 0.131 & 0.489 \\
\hline
\end{tabular}

Source: author calculations.

Chart 1 displays the impulse-response functions to a positive shock in CC indexes (kaopen and ka) after a one unit shock on a capital account (i.e., a rise by one weighted unit in capital account restriction). These effects are significant and happen rapidly following the shock; however, they remain for a short time. For the exchange rate re- 
sponse, the major portion happens in the first quarter ahead. The differential interest rate response is longer, lasting more than one year. This temporal difference in impact suggests that the loss of the autonomy of monetary policy is longer than the instability of the exchange rate. In the short run, applying CCs may allow the monetary policy to adapt the local interest rate, and reducing the vulnerability to higher instability of the exchange rate related to the occurrence of intensive short-term flows generated by the United States' monetary policy variations.

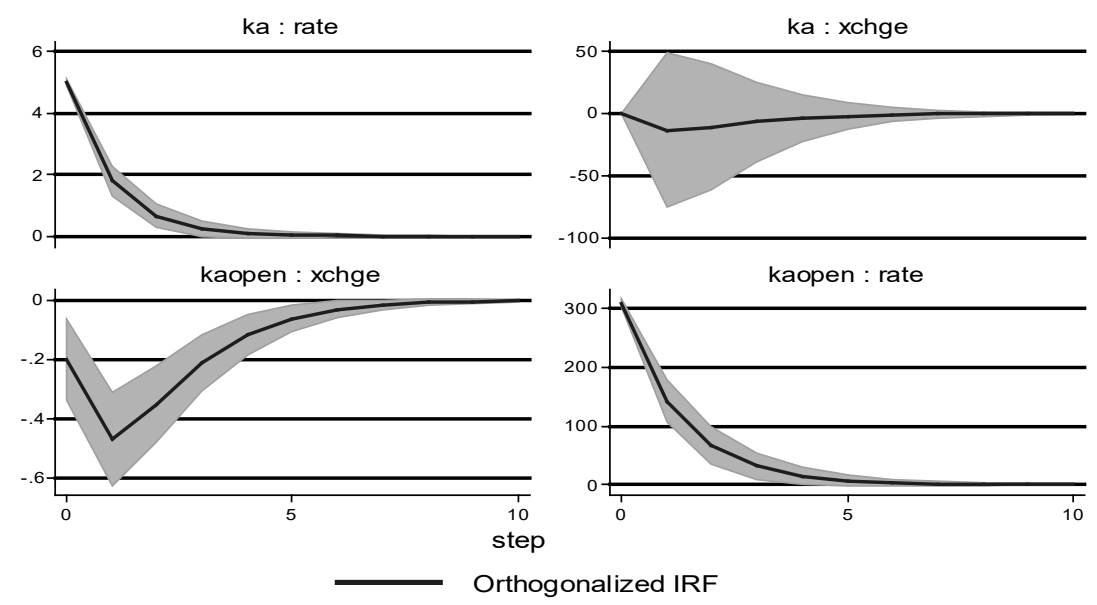

Chart 1. Impulse-response functions to positive capital control (ka and kaopen) shocks Source: IRF STATA Software.

The constraints of choosing economic policies in the context of the free movement of capital can be circumvented following an accumulation of international reserves. In the 2000s, several EEs sought an optimal combination aimed at safeguarding their autonomous monetary policy, stabilizing the exchange rate, and liberalizing the capital account via an accumulation of reserves (Bianchi et al. 2018). The results show positive and significant coefficients of "ka," "kaopen," and "kai" to explain the changes in international reserves; only the coefficient of controls on outflows (the "kao" index) is insignificant (Table 3).

These reserves made it possible to correct the impossibility of recourse to certain macroeconomic policies (Zehri 2020, b). Our results confirm this positive effect of reserves on monetary policy and on exchange rate policy; the coefficient of the variable "ir" is positive and significant in the equations that explain the differential interest rate and the exchange rate fluctuation.

The multilateral impacts of CC policies are important for many causes. First, CCs applied by the country receiving international flows may motivate flows to reach other recipient economies that do not apply such controls, aggravating their local financial instability. Second, CCs may obstruct foreign adjustment, for example, when controls on capital inflow are utilized to maintain a certain value of a currency. The cross-sec- 
tional equivalence of restrictions on capital flows is detected by the fixed-effects of each $\mathrm{EE}$ and, to a limited extent, by the international investment position changes.

We find proof that a net strict of inflow controls in the EEs (the kai index) produces effective spillovers to other economies, starting by driving these inflows into those economies and by causing tensions on their exchange rate. In response, the short-term interest rates of these countries will fall, to discourage these inflows. These reactions are short term and are difficult to detect statistically; the shock and the response to this shock happen in the same trimester. Our results (Table 3) show a positive and significant coefficient of "kai" in the equation of "spill." Additionally, the Chinn and Ito index "kaopen" is also positive and significant. These findings are in line with the literature evidence. The other indexes of capital controls on outflows and gross flows, "kao" and "ka," are insignificant.

In response to these high inflows and to counteract their negative effects on the domestic currency, the local policymakers react by strengthening inflow controls. This policy response is efficient and leads to a turnaround of the capital inflow in the next quarter, which causes a fall that covers the massive inflows of the previous period.

Our results, which show that CCs cause spillovers on the strategies of other economies, are backed up by theory. However, this study is among the first to discover empirical proof of these spillovers. Lu et al. (2017) examined the political response of one country following the intensive application of CCs by another. These capital controls provoked a negative externality and induced a similar reaction in the country that consequently received massive inflows of capital, also leading them to practice capital controls. Nevertheless, Lu et al. (2017) did not empirically verify this spillover effect.

The evidence for this spillover became clearer after the 2008 crisis. It was found that capital controls instituted by one country caused an appreciation of the currencies of other countries and a massive inflow of capital to these countries. During the following periods, these effects will gradually decrease and will end with the introduction of capital controls by other countries. There will then be a fall in inflows and an increase in the short-term interest rate differential.

\section{Conclusion}

The study examined the internal and external effects of capital controls in emerging economies after the 2008 crisis. We analyzed the impacts of variation in CCs through a new, elaborated dataset and by using a panel VAR approach. Concerning the impacts of CC, our major result is that the restrictions provided by the incompatibility triangle were formed by the policy decisions in emerging economies after the 2008 crisis. The governments of EEs have become more focused on quickly stabilizing their exchange rates while at the same time accepting the loss of their monetary policy independence. This combination of monetary policy, exchange rate policy, and CCs are similar to the 
suggestions of the trilemma. The EEs would like to shift away from the corners of this triangle, wanting to have more monetary autonomy, more exchange rate stability, and more financial openness. The analysis of the impact of capital controls has made it possible to highlight a return to greater monetary autonomy and also to have more stable exchange rates. These results are consistent with the findings of the literature, according to which, the liberalization of the movements of capital may lead to a lose of control over monetary policy and causes a high fluctuation of the exchange rate.

This analysis has several limitations, in particular, the CC indexes used and the choice of differential interest rate as an indicator of monetary policy autonomy. Although the differential in domestic and foreign interest rates is often seen as a proxy for the independence of the monetary policy (Borio and Gambacorta 2017), it is subject to debate. A decrease in this differential will not effectively convert into a loss of monetary autonomy, especially in countries with high inflation, which will consequently affect the exchange rate. In these circumstances, a fall in the differential interest rate, maybe originating from a tightening of United States monetary rules, can explain the inside inflation order and, consequently, the differential interest rate (Rudebusch and Williams 2016; Laséen, Pescatori, and Turunen 2017).

This study highlights the role of accumulating international reserves as an instrument to support Ees' macroeconomic policies. The results confirm that CCs did not prevent emerging countries from accumulating international reserves. After the crisis, these reserves made it possible to support the monetary and exchange rate policies of these countries. These reserves constitute a substitute for capital outflows following capital controls. The spillover effect is very noticeable after some countries introduced capital controls. It was noticeable that EEs were affected by massive capital inflows following the application of such controls. These restriction policies may affect other countries through reversal capital flows. This spillover may be explained by abundant international liquidity and the important role of investment funds (Miyajima and Shim 2014). The study shows evidence of spillover policy, which originates from the problem of coordination between EEs concerning the use of capital controls as an instrument to manage capital flows.

\section{References}

Alfaro, L., Chari, A., Kanczuk, F. (2017), The real effects of capital controls: Firm-level evidence from a policy experiment, "Journal of International Economics", 108, pp. 191-210. http://dx.doi.org/10.1016/j.jinteco.2017.06.004

Bayoumi, T., Gagnon, J., Saborowski, C. (2015), Official financial flows, capital mobility, and global imbalances, "Journal of International Money and Finance", 52, pp. 146-174. http://dx.doi.org/10.1016/j.jimonfin.2014.11.017

Benigno, G., Chen, H., Otrok, C., Rebucci, A., Young, E.R. (2013), Financial crises and macro-prudential policies, "Journal of International Economics", 89 (2), pp. $453-$ 470. http://dx.doi.org/10.1016/j.jinteco.2012.06.002 
Benigno, G., Chen, H., Otrok, C., Rebucci, A., Young, E.R. (2016), Optimal capital controls and real exchange rate policies: A pecuniary externality perspective, "Journal of Monetary Economics”, 84, pp. 147-165. http://dx.doi.org/10.1016/j.jmoneco .2016.10.004

Bianchi, J., Mendoza, M.E.G. (2011), Overborrowing, Financial Crises and "Macro-Prudential'Policy?, No. 11-24, International Monetary Fund. https://doi.org/10.5089/97 81455216710.001

Bianchi, J., Hatchondo, J.C., Martinez, L. (2018), International reserves and rollover risk, “American Economic Review”, 108 (9), pp. 2629-2670. http://dx.doi.org/10.12 57/aer.20140443

Borio, C., Gambacorta, L. (2017), Monetary policy and bank lending in a low interest rate environment: diminishing effectiveness?, "Journal of Macroeconomics", 54, pp. 217-231. http://dx.doi.org/10.1016/j.jmacro.2017.02.005

Chamon, M., Garcia, M. (2016), Capital controls in Brazil: effective?, "Journal of International Money and Finance”, 61, pp. 163-187. http://dx.doi.org/10.1016/j.jimon fin.2015.08.008

Chinn, M.D., Ito, H. (2008), A new measure of financial openness, "Journal of Comparative Policy Analysis”, 10 (3), pp. 309-322. http://dx.doi.org/10.1080/138769808 02231123

Devereux, M.B., Young, E.R., Yu, C. (2017), Capital Controls, Monetary Policy, and Sudden Stops. http://dx.doi.org/10.1016/j.jmoneco.2018.07.016

Edison, H.J., Warnock, F.E. (2003), A simple measure of the intensity of capital controls, "Journal of Empirical Finance", 10 (1-2), pp. 81-103. http://dx.doi.org/10.1016 /S0927-5398(02)00055-5

Farhi, E., Werning, I. (2014), Dilemma not trilemma? Capital controls and exchange rates with volatile capital flows, "IMF Economic Review", 62 (4), pp. 569-605. http:// dx.doi.org/10.1057/imfer.2014.25

Fernández, A., Rebucci, A., Uribe, M. (2015), Are capital controls countercyclical?, "Journal of Monetary Economics"”, 76, pp. 1-14. http://dx.doi.org/10.1016/j.jmone co.2015.07.001

Fernández, A., Klein, M.W., Rebucci, A., Schindler, M., Uribe, M. (2016), Capital control measures: A new dataset, "IMF Economic Review", 64 (3), pp. 548-574. http:// dx.doi.org/10.1057/imfer.2016.11

Forbes, K., Fratzscher, M., Straub, R. (2015), Capital-flow management measures: What are they good for?, "Journal of International Economics", 96, pp. S76-S97. http://dx .doi.org/10.1016/j.jinteco.2014.11.004

Forbes, K., Reinhardt, D., Wieladek, T. (2017), The spillovers, interactions, and (un) intended consequences of monetary and regulatory policies, "Journal of Monetary Economics”, 85, pp. 1-22. http://dx.doi.org/10.1016/j.jmoneco.2016.10.008

Glick, R., Hutchison, M. (2005), Capital controls and exchange rate instability in developing economies, "Journal of International Money and Finance", 24 (3), pp. 387-412, http://dx.doi.org/10.1016/j.jimonfin.2004.11.004

Ito, H., McCauley, R.N., Chan, T. (2015), Currency composition of reserves, trade invoicing and currency movements, "Emerging Markets Review", 25, pp. 16-29. http:// dx.doi.org/10.1016/j.ememar.2015.11.001 
Jeanne, O. (2016), The macroprudential role of international reserves, "American Economic Review”, 106 (5), pp. 570-573. http://dx.doi.org/10.1257/aer.p20161013

Kim, S., Yang, D.Y. (2012), International monetary transmission in East Asia: Floaters, non-floaters, and capital controls, "Japan and the World Economy", 24 (4), pp. 305316. http://dx.doi.org/10.1016/j.japwor.2012.05.003

Klein, M.W., Shambaugh, J.C. (2015), Rounding the corners of the policy trilemma: sources of monetary policy autonomy, "American Economic Journal: Macroeconomics", 7 (4), pp. 33-66. http://dx.doi.org/10.1257/mac.20130237

Korinek, A. (2011), The new economics of prudential capital controls: A research agenda, "IMF Economic Review", 59 (3), pp. 523-561. http://dx.doi.org/10.1057/imfer.2011.19

Korinek, A. (2018), Regulating capital flows to emerging markets: An externality view, "Journal of International Economics", 111, pp. 61-80. http://dx.doi.org/10.1016/j.jin teco.2017.12.005

Lambert, F.J., Ramos-Tallada, J., Rebillard, C. (2011), Capital controls and spillover effects: evidence from Latin-American countries, Banque de France Working Paper No. 357. http://dx.doi.org/10.2139/ssrn.1980091

Laséen, S., Pescatori, A., Turunen, J. (2017), Systemic risk: A new trade-off for monetary policy?, "Journal of Financial Stability", 32, pp. 70-85. http://dx.doi.org/10.10 16/j.jfs.2017.08.002

Liu, Z., Spiegel, M.M. (2015), Optimal monetary policy and capital account restrictions in a small open economy, "IMF Economic Review", 63 (2), pp. 298-324. http://dx.doi .org/10.1057/imfer.2015.8

Lu, Y., Tao, Z., Zhu, L. (2017), Identifying FDI spillovers, “Journal of International Economics”, 107, pp. 75-90. http://dx.doi.org/10.1016/j.jinteco.2017.01.006

Magud, N.E., Reinhart, C.M., Rogoff, K.S. (2011), Capital controls: myth and reality-a portfolio balance approach, No. w16805, Peterson Institute for International Economics Working Paper No. 2011-07. http://dx.doi.org/10.2139/ssrn.1773692

Magud, N.E., Reinhart, C.M., Rogoff, K.S. (2018), Capital controls: myth and reality - a portfolio balance approach, "Annals of Economics and Finance", 19 (1), pp. 1-47.

Ocampo, J.A., Spiegel, S., Stiglitz, J.E. (2008), Capital market liberalization and development, "Capital Market Liberalization and Development", pp. 1-47. http://dx.doi .org/10.1093/acprof:oso/9780199230587.001.0001

Pasricha, G.K., Falagiarda, M., Bijsterbosch, M., Aizenman, J. (2018), Domestic and multilateral effects of capital controls in emerging markets, "Journal of International Economics”, 115, pp. 48-58. http://dx.doi.org/10.1016/j.jinteco.2018.08.005

Passari, E., Rey, H. (2015), Financial flows and the international monetary system, "The Economic Journal”, 125 (584), pp. 675-698. http://dx.doi.org/10.1111/ecoj.12268

Qureshi, M.S., Ostry, J.D., Ghosh, A.R., Chamon, M. (2011), Managing capital inflows: The role of capital controls and prudential policies, No. w17363, NBER Working Paper Series. https://doi.org/10.3386/w17363

Rebucci, A., Ma, C. (2019), Capital controls: A survey of the new literature, No. w26558, National Bureau of Economic Research. http://dx.doi.org/10.2139/ssrn.3495987

Rey, H. (2015), Dilemma not trilemma: the global financial cycle and monetary policy independence, No. w21162, National Bureau of Economic Research. 
Rudebusch, G.D., Williams, J.C. (2016), A wedge in the dual mandate: Monetary policy and long-term unemployment, "Journal of Macroeconomics", 47, 5-18. http://dx .doi.org/10.1016/j.jmacro.2015.05.001

Zehri, C. (2020a), Capital Restrictions Policies, Currency Appreciation and Foreign Debts. "Montenegrin Journal of Economics", 16 (3), 149-159. https://doi.org/10.142 54/1800-5845/2020.16-3.12

Zehri, C. (2020b), Conditions for the success of capital controls: The elasticity approach. "International Journal of Finance \& Economics". Articles in press. https:// doi.org/10.1002/ijfe.2182

\section{Streszczenie}

\section{Wielorakie skutki kontroli przepływu kapitału}

Kontrola kapitału jest postrzegana jako metoda zapewnienia stabilności finansowej lub poprawy programu dostosowań makroekonomicznych w gospodarkach, w których występują sztywności nominalne i nieoptymalna polityka pieniężna. Taka kontrola może przybierać różne formy, w tym jawnego lub ukrytego opodatkowania transgranicznych przepływów finansowych oraz wprowadzenia systemu podwójnych lub wielokrotnych kursów walutowych. Wykorzystując kwartalne dane dotyczące kontroli kapitału w 27 gospodarkach wschodzących w latach 2010-2018, przeanalizowano skuteczność kontroli kapitału pod różnymi kątami. Od kryzysu finansowego w 2008 r. wzmocnienie kontroli kapitału umożliwiło zwiększenie autonomii polityki pieniężnej i stabilności kursu walutowego, zgodnie z założeniami modelu Mundella-Fleminga. Wyniki analizy pokazują, że gromadzenie rezerw międzynarodowych może rekompensować utratę wpływów i prowadzić do realizacji bardziej skutecznej polityki. Silniejsza kontrola napływu kapitału powoduje znaczne skutki uboczne, szczególnie w warunkach nadmiernej płynności. Te zewnętrzne efekty wynikają z problemu koordynacji polityki gospodarek wschodzących i są głównie spowodowane przez kontrolę kapitału stosowaną jako instrument zarządzania przepływami kapitału. W działaniach rządów, które muszą zarządzać ryzykiem związanym z gwałtownym napływem lub odpływem kapitału, kontrola kapitału powinna odgrywać kluczową rolę.

Słowa kluczowe: kapitał, kontrola, przepływy, skutki

JEL: F21, F32, F41, F42 